Historic, Archive Document

Do not assume content reflects current scientific knowledge, policies, or practices. 



\section{Select List of \\ Chrysanthemums for 1917}

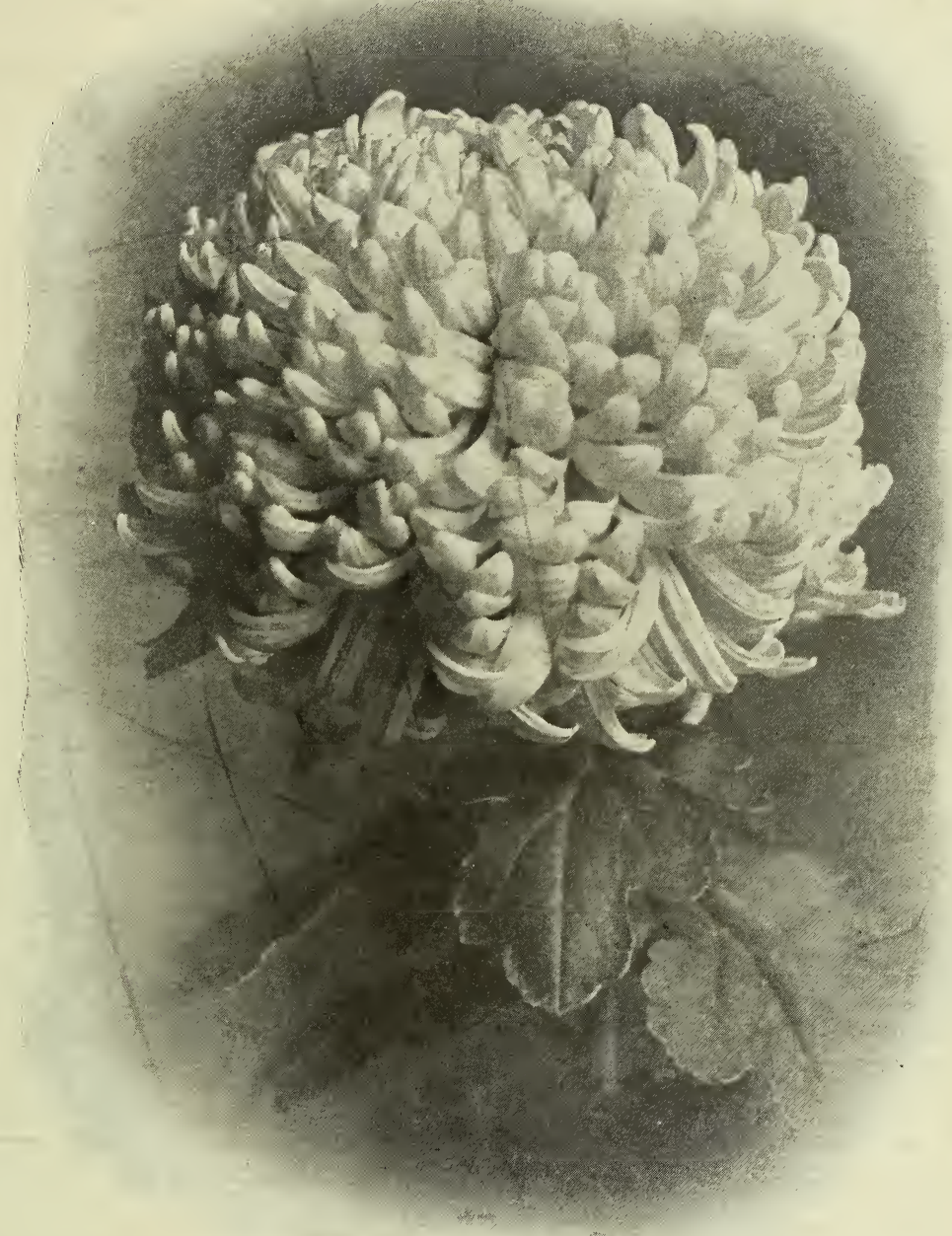

MISS ANOLA WRIGHT

\section{ELMER D. SMITH ADRIAN, MICHIGAN}




\section{IMPORTANT-READ CAREFULLY.}

All plants are grown in 21/4-inch pots, and delivered as soon as they are strong enough.

Kindly remit full amount. Remittances should be made by Postoffice or Express money order or Draft. All letters containing money should be sent by registered mail. Those desiring to open an account must send references, preferably from banks or firms with whom credit relations have existed. We do not ship plants C. O. D. unless assured of acceptance by a remittance of $25 \%$ of the amount of the order.

TRANSPORTATION.-In most cases plants travel better and are more satisfactory to the recipient when forwarded by Express, and we recommend this method above all others. We invariably ship by express unless otherwise instructed.

EXPRESS FACILITIES.-Our local companies are the American and Wells-Fargo, who, under the new schedule, agree to transport and deliver plants, either themselves or by the assistance of the Adams, Canadian, Canadian Northern, Dominion, Globe, Great Northern, National, Northern, Southern and Western Express Companies, to destination; the rate being the same when handled by one or more companies and whether sent collect or prepaid.

PARCEL POST.-Many have been misled in the belief that parcel post is cheaper than express. There are but two cases where it is less: first, small packages of five pounds or less; second, shipments to the first three zones, or within 300 miles from Adrian.

The following table shows amount of charges by Express and Parcel Post:

\begin{tabular}{|c|c|c|c|c|c|c|}
\hline & \multicolumn{2}{|c|}{$-5 \mathrm{lbs} .{ }_{-}$} & \multicolumn{2}{|c|}{$-10 \mathrm{lbs}$} & \multicolumn{2}{|c|}{$-20 \mathrm{lbs}}$. \\
\hline Zones & Exp. & P.P. & Exp. & P.P. & Exp. & $\begin{array}{l}\text { P.P. } \\
\$ 0.83\end{array}$ \\
\hline $\begin{array}{l}\text { Baltimore } \\
\text { Boston }\end{array}$ & $\begin{array}{r}\$ 0.29 \\
.30\end{array}$ & $\$ 0.23$ & $\begin{array}{r}\$ 0.29 \\
.30\end{array}$ & $\$ 0.45$ & $\begin{array}{r}\$ 0.42 \\
.46\end{array}$ & $\begin{array}{r}\$ 0.83 \\
1.22\end{array}$ \\
\hline Denver & .41 & .41 & .47 & .81 & .78 & 1.61 \\
\hline Indianapolis & .25 & .14 & .25 & .24 & .30 & .44 \\
\hline Phoenix & .50 & .51 & .75 & 1.01 & 1.34 & 2.01 \\
\hline San Francisco & .67 & .60 & .85 & 1.20 & 1.50 & 2.40 \\
\hline
\end{tabular}

From the foregoing it will be seen that the longer the haul and the heavier the package the greater the saving when shipped by Express.

To localities not reached by express we will forward by Parcel Post, but we cannot become responsible for their delivery. All such shipments must be prepaid and will travel solely at owner's risk.

NO GUARANTEE.-While we exercise the utmost care in executing all orders, to keep our stock true to name, we give no warranty, expressed or implied, and cannot guarantee or be in any way responsible for the crop, either as to variety or product. If not accepted on these terms they must be returned at once. 


\section{To Our Correspondents:-}

It is again our pleasure to present this catalogue for 1917 to the many patrons as well as all prospective clients.

The new varieties being sent early in the year are of the highest standard.

The General List of Standard kinds is undoubtedly the largest offered by any firm in this Country.

Next March will be our Tumenty-seventh anniversary in originating and distributing new varieties of Chrysanthemums. Looking back over the period of over a quarter century it affords us great pleasure when we realize the large number of meritorious kinds that fortune has permitted us to give the Chrysanthemum enthusiasts of America. Still the Zenith has not been reached, for each year the improvement either in color, size or form continues.

For ten years we have confined ourselves exclusively to the culture of Chrysanthemums.

\section{KEEP THIS CATALOGUE FOR REFERENCE.}

This Catalogue is really a book of reference, giving the height the plants attain. and the best bud to reserve for the many sorts offered. Such imformation is eagerly sought each year, and especially so as the time for securing buds draws near. Every word in this Catalogue from cover to cover is worth reading and may throw light upon some subject important to the recipient. 


\section{EXHIBITION SECTION \\ Chrysanthemum Novelties for 1917 \\ Deliveries to Begin About February 15}

Miss Anola Wright.-Rose pink in color, resembling Chieftain or Dr. Enguehard, or possibly intermediate between the two, having less of violet or lavender of the former and slightly softer than the latter when seen at its best. Of large size, $81 / 2$ inches or more in diameter. A strong grower with medium sized foliage; its only weak point is, the stem is scarcely strong enough to hold the large bloom erect without support, but is no worse than many exhibition sorts. It eclipses Lady Hopetoun and Wells' Late Pink in color, possessing a more rosy tint. Buds selected August 30 th, or soon after, produce the best blooms.

Price-\$1.50 each; $\$ 12.50$ per ten. See cut, front cover.

\section{INTRODUGTION OF 1916}

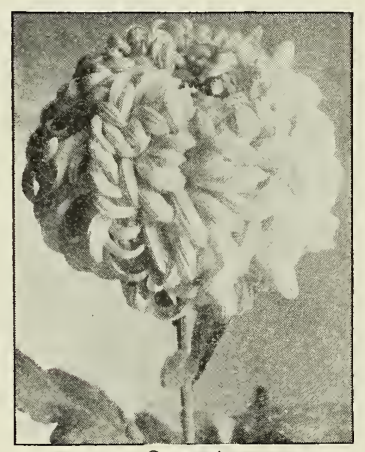

Ogontz

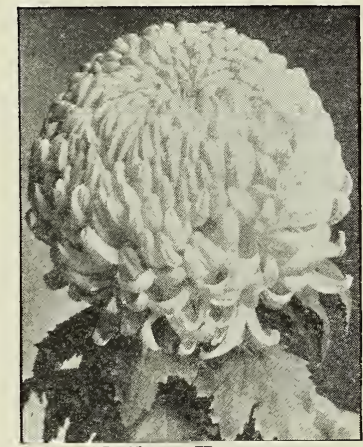

Yellow Turner

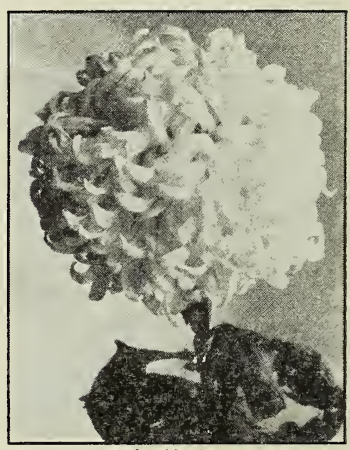

Artista

50 c each; $\$ 4.00$ per ten; $\$ 35.00$ per hundred, except where otherwise quoted.

Not less than 5 plants of a variety at ten, and 25 at hundred rate.

Best bud.

8/20 Artista.- One of the largest exhibition varieties we have raised. White with a slight creamy tint in the depths of petals. Matures last days of October. Dwarf.

8/25 Autumn Splendor.-Color is a golden pink as the name implies. Large, full, stem ridged and easy to manage. Dwarf.

8/20 Miss Elvia Scoville. $-A$ pure write sport from Wells. Late pink, possessing all $\therefore$ the good qualities of its parent. Dwarf. 30e each; $\$ \mathbf{2 . 5 0}$ per ten; $\$ 20.00$ per hundred.

8/10 Mrrs. J. Gibson.-Color light pink, shading deeper at end of petals, of large size, good stem and foliage. Semi-dwarf.

8/30 Ogontz.-A seedling from Nakota which it greatly resembles, the greatest difference being in color which is light yellow. Semi-dwarf.

8/10 Wm. Righy.-A light yellow sport from Mrs. Gilbert Drabble, equal in size. Dwarf.

$\delta / 30$ Iellow 'Turner.-This is also a light yellow sport from the popular Wm. Turner and is equal to its parent in every respect. Semi-dwarf. 


\section{STANDARD VARIETIES}

We are aware some of the best blooms are produced from buds taken August 5th, but throughout the Middle West buds of most varieties, taken prior to August 15th, suffer from excessive heat and lack of moisture, and for this reason we secure our best results from those taken August 15th to 30th. Each grower must be governed by the conditions in his immediate locality, and may find it advantageous to take them earlier than dates given.

In determining the height, those which do not exceed $4 \mathrm{ft}$. are designated as Dwarf; those which do not exceed $6 \mathrm{ft}$. as SemiDwarf, and those growing taller as Tall. These deductions are only approximate and from stock propagated in February.

Not less than 5 plants of a variety at ten, 25 at hundred rate.

Best Bud.

8/25 Adele Griswold.-One of the large bright pinks, fine stem and foliage. Dwarf. 15e each; $\$ 1.20$ per teu; $\$ 10.00$ per hundred.

$8 / 25$ Adonis.-(Introduced by us 1910.) A beautiful pink of a decided reflexed form. useful for late exhibitions. Tall. 15e each; \$1.20 per ten; \$10.00 per hundred.

8/25 Algonac.-(Introduced by us 1915.) White with a slight creamy tint at center. High rounded incurved blooms. Strong dwarf growth. 15e each; $\$ 1.20$ per ten; \$10.00 per hundred.

$8 / 10$ Alice Lemon.-A soft shade of pink and of the largest size. Very early bud is imperative, otherwise it is single. Dwarf.

15e each; $\$ 1.20$ per ten; $\$ 10.00$ per hundred.

8/20 Antigone.-Pure white, large double flower. Early midseason, dwarf habit. 10e each; soe per ten; \$6.00 per hundred.

$8 / 20$ Artistic Queen.-(Introduced by us 1912.) The blooms are loosely incurved, of the largest size, resting upon heavy foliage and supported by a very rigid stem. Color, a light rose pink. Dwarf.

10e each; Soe per ten; $\$ 6.00$ per hundred.

$8 / 10$ Ben Wells.-One of the largest exhibition whites. Dwarf. 15e each; $\$ 1.20$ per ten; $\$ 10.00$ per hundred.

8/25 Black Hawk.-Dark Crimson scarlet, exceptionally fine color. Semi-dwarf. 10e each; soc per ten; $\$ 6.00$ per hundred.

8/5 Bob Pulling.-Very large, orange rellow, one of the best exhibition sorts. Easy to grow, producing beautiful foliage up to the flower. Dwarf. 25e each; $\$ 2.00$ per ten; $\$ 15.00$ per hundred.

8/15 Brighthurst.-(Introduced by us 1903.) Pink, slightly shading to cream. Semidwarf.

10e each; Soc per ten; $\$ 6.00$ per hundred.

$8 / 15$ Bronze Brighthurst.-A bronze colored sport of the old favorite Brighthurst. Semi-dwarf. 10e each; soe per ten; $\$ 6.00$ per hundred.

8/25 Calumet.-(Introduced by us 1915.) The best exhibition bronze to date; rather early for late shows, but its large size, the high percentage of perfect blooms and its easy culture make it one of the best. Tall.

15e each; \$1.20 per ten; $\$ 10.00$ per hundred.

$\delta / 10$ Chas. H. Totty.-Chestnut, with old gold reverse; an easy grower of large size. Semi-dwarf.

15e each; $\$ 1.20$ per ten; $\$ 10.00$ per hundred.

8/10 Cheltoni.-A yellow sport from Nellie Pocket. Dwarf. 10e each; Eoc per ten; \$6.00 per hundred.

8/15 Christy Mathewson.-(Introduced by us 1912.) A Japanese of largest size, eight inches in diameter and six and one-half inches deep. In early development it shows an eye, but continues to produce more petals day by day until the center is filled. Pure white. Strong, wiry stem. Semi-dwarf. 10e each; Soc per ten; $\$ 6.00$ per hundred.

\&/20 Chrysanthemiste Montigny.-A large Japanese incurved; light sulphur yellow. Tall. ise each; $\$ 1.20$ per ten; $\$ 10.00$ per hindred. 8/25 Daily Mail.-An extra large incurved yellow. Very tall grower with heavy foliage.
The stem is scarcely strong enough to sustain the bloom, but for short stem collections will be very acceptable owing to its size and finish. Tall. 15e each; $\$ 1.20$ per ten; $\$ 10.00$ ber hundred.

$8 / 25$ Dakoma.-(Introduced by us 1907.) A fine exhibition bronze, of large size and beautiful form. Dwarf.

15e eaeh; $\$ 1.00$ per ten; $\$ 10.00$ per hundred. 
S/25 Dragon Vert.-A large crimson with golden reverse; petals are regular and full in their arrangement. Stiff stem and a free grower. Dwarf. 25 c cach; $\$ 2.00$ per ten; $\$ 15.00$ per hundred.

8/15 Earl Kitchener.-An enormous flower and a color none too plentiful at exhibitions, amaranth with silvery reverse. Semi-dwarf. 15 c each; $\$ 1.20$ per ten; $\$ 10.00$ per hundred.

$8 / 25$ Elberon.-(Introduced by us 1913.) Bright pink, finest incurved form, beautiful foliage and good stem, easy to manage. Semi-dwarf. 10c each; 80c per ten; $\$ 6.00$ per hundred.

8/25 Fatouma.-The blooms are incurved, of a rosy amber color, and of fine build. Full exhibition size, with good stem and foliage. Semi-dwalf. 15c each; $\$ 1.20$ per ten; $\$ 10.00$ per hundred.

$8 / 20$ Flamingo.-(Introduced by us 1914.) A bright crimson with perfectly reflexed flowers, showing the intense color to best advantage. Dwarf. 25e each; $\$ 2.00$ per ten; $\$ 15.00$ per hundred.

8/15 rancis Jollife.-An enormous flower, creamy yellow petals edged with a broad band of pink. Semi-dwarf. 15c each; $\$ 1.20$ per ten; $\$ 10.00$ per hundred.

8/10 F. S. Vallis. - A very large yellow, desirable for collections on short stems. Semidwarf. 10c each; Soc per ten; $\$ 6.00$ per hundred.

$\delta / 15$ Geo. J. Bruzard.-Wine red, broad florets. One of the largest for collections. Semi-dwarf.

15c each; $\$ 1.20$ per ten; $\$ 10.00$ per hundred.

8/20 Glen Cove-(Introduced by us 1911.) Japanese, light lavender pink; few pinks excel this variety in size, and its sturdy stem admits of staging without supports. Semi-dwarf.

15c each; $\$ 1.20$ per ten; $\$ 10.00$ per hundred.

8/30 Glenview.-The large Japanese blooms are dark bronze, sometimes showing a little of the Indian red lining. It is also a good commercial bronze, giving the double flowers from late buds. Semi-dwarf.

15c each; \$1.20 per ten; \$10.00 per hundred.

8/20 Gorgeous.-A golden-yellow Japanese. Large, broad flowers of fine form. Foliage is short and leathery. Semi-dwarf.

10c each; soc per ten; $\$ 6.00$ per hundred.

$9 / 5$ Harry E. Conversc.-Growth vigorous, clean foliage, large blooms, petals crimson with golden bronze reverse, which is the predominating color. Semi-dwarf. 20 e each; $\$ 1.75$ per ten; $\$ 12.00$ per hundred.

8/25 His Majesty.-A vivid crimson; growth vigorous, stiff stem and perfect foliage. Dwarf.

15c each; $\$ 1.20$ per ten; $\$ 10.00$ per humdred.

$8 / 5$ Hon. Mrs. Lopes.-A very large yellow, but, like many of the importations, an early bud is important to secure double flowers. Dwarf.

10c each; soc per ten; $\$ 6.00$ per hundred.

8/25 Howard Gould.--Inside of petals bright golden chestnut. Reverse, pure deep gold. Dwarf.

15c each; \$1.20 per ten; $\$ 10.00$ per hundred.

8/5 James Fraser.-A decided reflexed. The long ribbon-like petals hang down to the foliage. Canary yellow; closely resembles F. S. Vallis, but has a much stronger stem; is equally large. Semi-dwarf. 15c each; \$1.20 per ten; $\$ 10.00$ per hundred.

8/10 J. Lock.-Bright yellow, streaked red; broad and long florets, blooms extra large. Dwarf.

15c each; $\$ 1.20$ per ten; $\$ 1.0 .00$ per hundred.

9/10 Kewanee.-(Introduced by us 1915.) Color Chamois, very distinct, of large incurved form. Should be in every exhibition collection. Tall. 15c each; $\$ 1.20$ per ten; $\$ 10.00$ per hundred.

8/25 Lady Hopetoun.-Light pink: a very fine-formed bloom. Dwarf. 15c each; 1.20 per ten; $\$ 10.00$ per hundred.

8/15 Lenox.-(Introduced by us 1911.) The largest yellow known; in fact, there are but a few in our large collection that equal it in size. Beautiful loosely incurved. and a bright, pleasing shade of yellow; many of our blooms are 9 in. in diameter and $7 \frac{1}{2}$ in. in depth; unexcelled for exhibitions. Semi-dwarf. 10c each; soc per ten; $\$ 6.00$ per hundred.

8/25 Lord Hopetoun.-Bright crimson, with golden reverse; one of the best. Dwarf. 15e each; $\$ 1.20$ per ten; $\$ 10.00$ per hundred. 

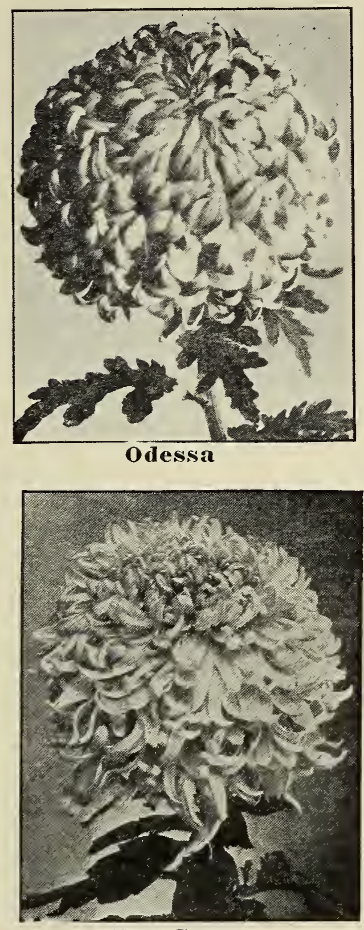

Gien Cove

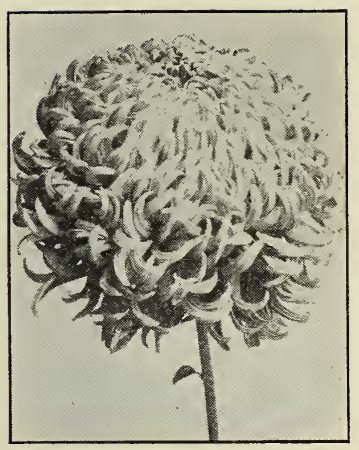

Harry E. Converse

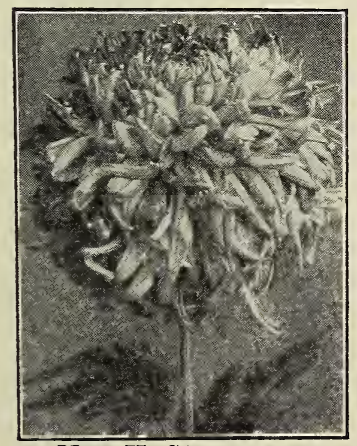

IIrs. H. Stevens

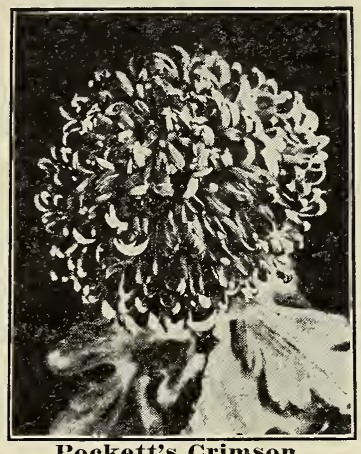

Pockett's Crimson

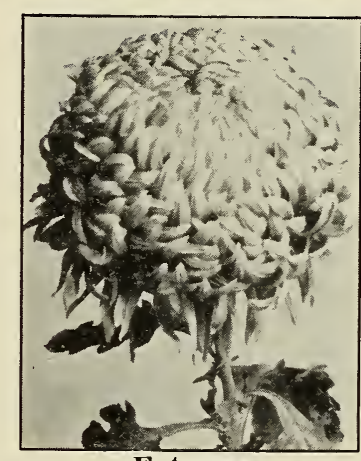

Fatouma

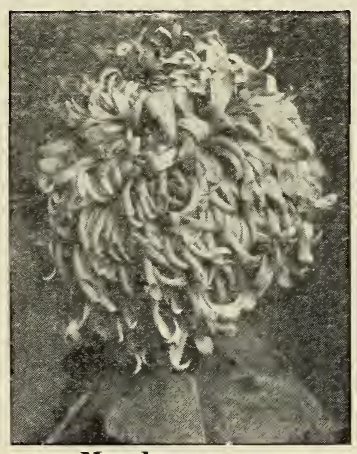

Meudon

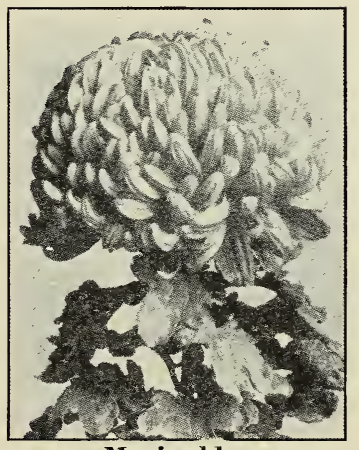

Marigold

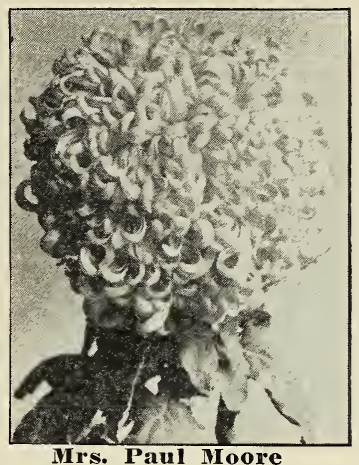

Mrs. Paul Moore

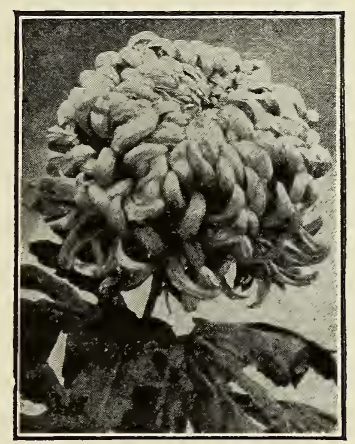

Ongawa

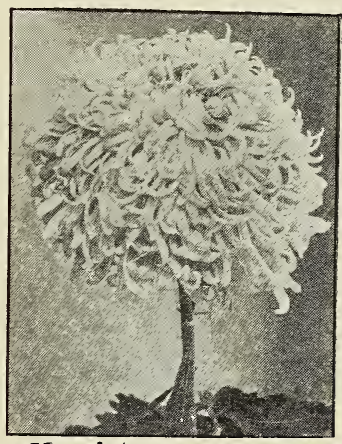

Morristown

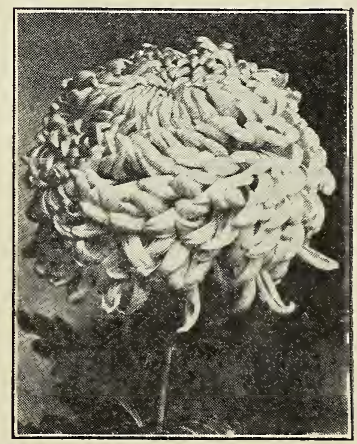

Nakota 
8/30 Lucile Quinlan.-(Introduced by us 1913.) Bright yellow, loosely incurved, and is useful for either exhibition or commercial purposes. Semi-dwarf. 10c each; soe per ten; \$6.00 per hundred.

9/5 Manhattan.-(Introduced by us 1912.) Color, delicate blush or flesh, which illuminates beautifully under artificial light. Semi-dwarf.

10c each; soc per ten; $\$ 6.00$ per hundred.

8/25 Mankato.-(Introduced by us 1915.) Purplish rose or amaranth of the refiexed form. Sturdy upright growth. Semi-dwarf.

15c each; 1.20 per ten; $\$ 10.00$ per hundred.

8/20 Marigold.-(Introduced by us 1915.) Unsurpassed in size and color which is the brightest yellow. Maturing the last of October; is useful for early exhibitions. Semi-dwarf.

10c each; soc per ten; \$6.00 per hundred.

8/15 Mary Doncllan.-An excellent Japanese incurved; broad petals of great substance, brightest yellow with reverse of same shade. Tall.

15e each; \$1.20 per ten; \$10.00 per hundred.

8/15 Mary Mason.-Rosy bronze, with lighter reverse; outer petals reflex, while center ones incurve, showing reverse. Dwarf. 15e cach; $\$ 1.20$ per ten; $\$ 10.00$ per hundred.

$8 / 20$ Meudon.-Dark pink. Its immense size makes it most acceptable for those interested in exhibitions, especially in the short-stemmed classes. Dwarf. 15e each; $\$ 1.20$ per ten; $\$ 10.00$ per hundred.

8/15 M. Loiseau-Rousseam.-Large, incurving pink in two tones of color; fine stem and foliage. Exceedingly large and bold; should be in every collection. Tall. 15e each; \$1.20 per ten; $\$ 10.00$ per hundred.

8/15 Miss Clay Frick.- White sport from Wm. Duckham, possessing the same good qualities. Free to grow and easy to manage. Dwarf.

1ce each; soc per ten; $\$ 6.00$ per hundred.

8/15 Miss Emma Roope.-Mauve pink with gold foliage and erect stem, reflexed. Dwarf.

15e cach; $\$ 1.20$ per ten; $\$ 10.00$ per hundred.

8/15 Miss L. M. Bennett.-Rich crimson in color with fine stem and foliage and one of the largest of its class. Semi-dwarf.

15e each; $\$ 1.20$ per ten; $\$ 10.00$ per hundred.

$8 / 20$ Miss Maude Jefries.-California growers consider this one of the best whites for their use, either commercially or for exhibitions. An incurved pure white. Very dwarf.

15e each; \$1.20 per ten; \$10.00 per hundred.

8/25 Miss Mariam Mankey.-Mauve pink Japanese incurved; is inclined to come late. Semi-dwarf.

15e cach; $\$ 1.20$ per ten; $\$ 10.00$ per hundred.

8/15 Modesto.-An intense yellow, fine incurved form. Dwarf. 10c each; s0c per ten; $\$ 6.00$ per hundred.

8/10 Morristown.-(Introduced by us 1911.) Unsurpassed in size by any pink; long reflexing outer petals with incurved center. When seen at its best it outranks any pink we know of. Semi-dwarf. 10c each; soc per ten; $\$ 6.00$ per hundred.

$8 / 30$ Mrs. D. F. Roy.-Mahogany red from August buds, but very bright from those selected in September. Tall.

15e each; \$1.20 per ten; $\$ 10.00$ per hundred.

$8 / 15$ Mrs. Fdgar J. Slater.-Long reflexed and curling florets of medium width. Color a rich amber. Semi-dwarf.

15e each; \$1.20 per ten; \$10.00 per hundred.

8/15 Mrs. Ernest Wild.-Chestnut crimson with bronze reverse. Nice upright growth and clean foliage; very promising. Semi-dwarf. 15e each; $\$ 1.20$ per ten; $\$ 10.00$ per hundred.

8/15 Mrs. G. Lloyd Wigg.-Light yellow; one of the largest of this color. Semi-dwarf. 15e each; \$1.20 per ten; $\$ 10.00$ per hundred.

$8 / 20$ Mrs. G. G. Mason.-Color distinct blood red with golden reverse; decided reflexed form; fine for collections. Semi-dwarf. 30c each; $\$ 2.50$ per ten; $\$ 20.00$ per hundred. $8 / 10$ Mrs. Geo. Hunt.-Large, soft yellow Japanese incurved. A grand exhibition variety
of robust growth. Dwarf. 15c each; \$1.20 per ten; \$10.00 per hundred.

$8 / 10$ Mrs. Gilbert Drabble.-This variety conforms in every way to the American ideal; stem rigid, foliage well up to the bloom, and is of the largest size. Purest white in color, and the petals are arranged in a whorl, rendering it most attractive. 25e each; $\$ 2.00$ per ten; $\$ 15.00$ per hundred. 


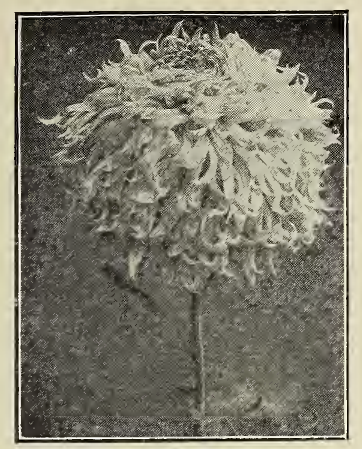

Adonis

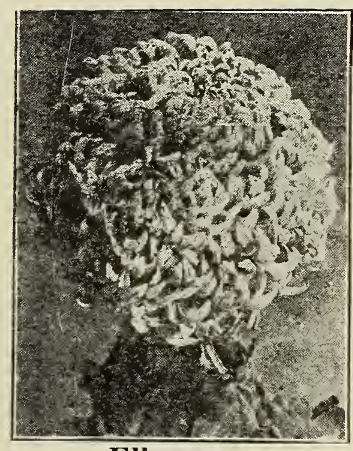

Elberon

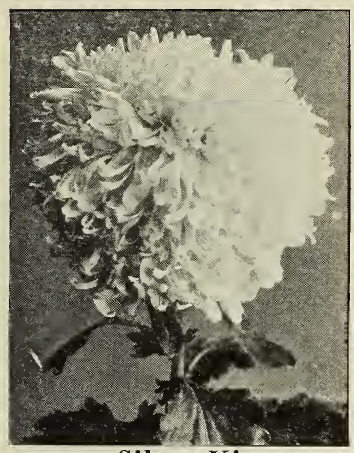

Silver King

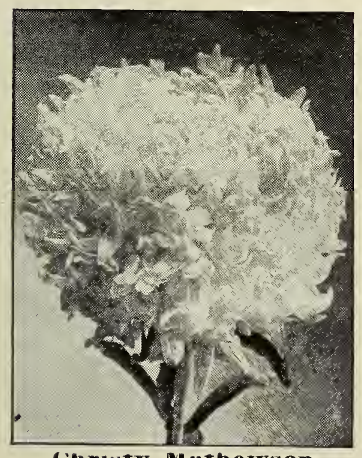

Christy Mathewson

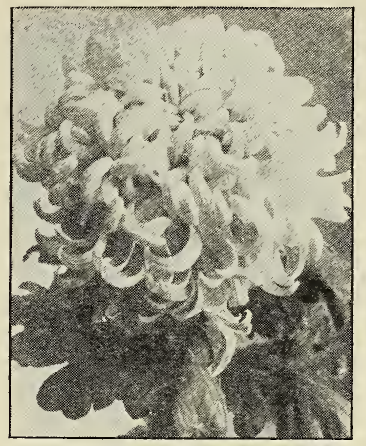

Artistic Queen

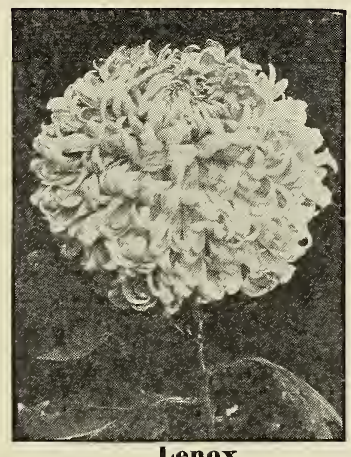

Lenox

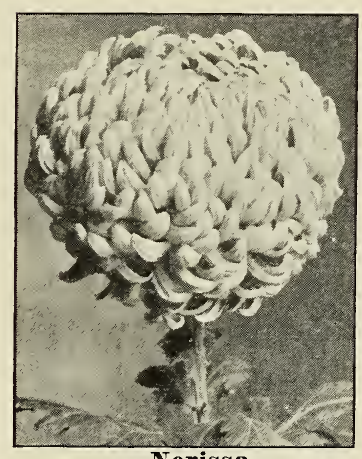

Nerissa

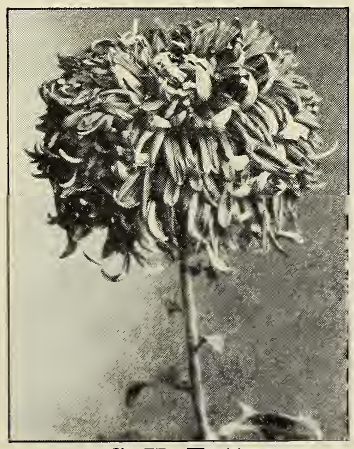

C. H. Totty

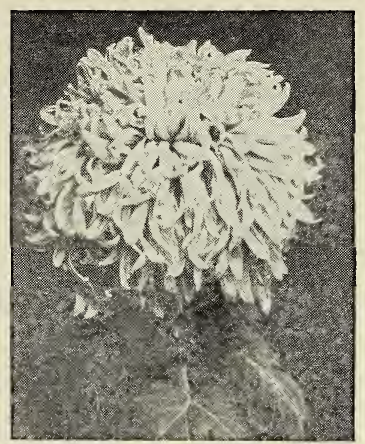

Wells' Late Pluh

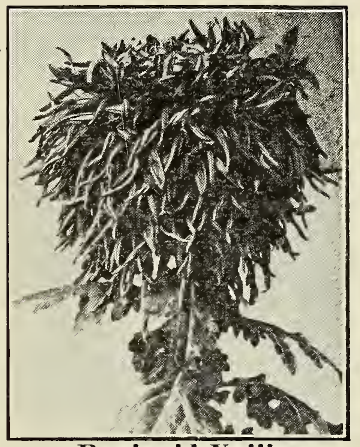

Reginald Vallis

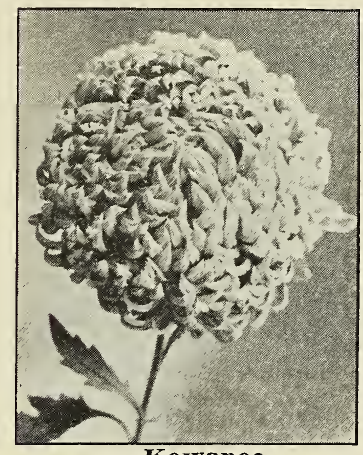

Kewanee

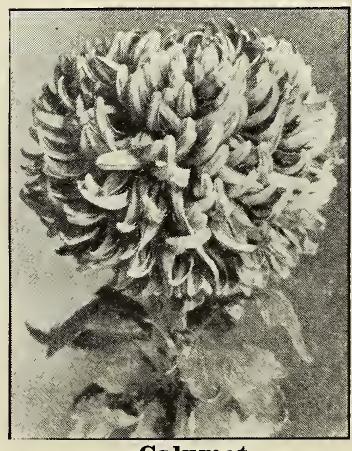

Calumet 
8/15 Mrs. I. Stevens.-A large golden bronze, fine form and perfect finisli. Dwarf. 15e eaeh; $\$ 1.20$ per ten; $\$ 10.00$ per hundred.

8/25 Irs. Hary Turner-A lovely crimson, showing a color as deep as the old 131 ack Hawk, with a flower of good size. Stem and foliage perfect. Semi-dwarf.

15e each; \$1.20 per ten; $\$ 10.00$ per hundred.

8/10 Mrs. H. J. Jones.-The color is a true chartreuse green when opening, changing to a rich, deep yellow. True Japanese in form, of the largest size. Tall. 15e eaeh; \$1.20 per ten; $\$ 10.00$ per hundred.

8/20 Mrs. J. A. Miller.-A large, high-built Japanese; reddish bronze. Semi-dwarf. ioc each; soe per ten; $\$ 6.00$ per hundred.

8/15 Irs. J. E. Dunne.-Salmon terra cotta Japanese; good color and very effective. Tall. 10e eaeh; soe per ten; $\$ 6.00$ per hundred.

\&/15 Mrs. J. C. Neill.-A soft canary yellow; fine incurved form; of easy cultivation and one of the best. Semi-dwarf. 10e each; soe per ten; $\$ 6.00$ per hundred.

8/20 Mrs. J. P. Mitchel.-Very large reflexed, pure white, admirably adapted for exhibition collections. Dwarf.

15e each; \$1.20 per ten; $\$ 10.00$ per hundred.

9/5 Mrs. Iaura B. Morris.-An exception to most yellow sorts, being bright rather than light yellow. Same strong habit as its parent, Thanksgiving Queen. Excellent for late shows. Dwarf.

15e eaeh; $\$ 1.20$ per ten; $\$ 10.00$ per hundred.

8/12 Irs. May Iunter.-Very popular on the Pacific coast, where it is considered the very best pink for exhibition use. The color is described as that of the La France rose.. Tall.

10e eaeh; soc per ten; $\$ 6.00$ per hundred.

8/20 Mrs. o. H. Kahn.-A fine bronze; should not be overlooked by commercial growers. Dwarf.

15e eaeh; $\$ 1.20$ per ten; $\$ 10.00$ per hundred.

8/25 Mrs. Paul Moore.-Too early for late exhibitions, of dwarf habit and full exhibition size. Color light yellow. Semi-dwarf. 15e eaeh; $\$ 1.20$ per ten; $\$ 10.00$ per hundred.

8/10 Mrs. R. C. Pulling.-A light yellow of the largest size; especially adapted for exhibition use where large blooms are required. Semi-dwarf. 15e eaeh; $\$ 1.20$ per ten; $\$ 10.00$ per hundred.

8/10 Mrs. R. H. Boggs.-One of the largest reflexed whites, excellent for exhibitions. Dwarf.

15e eaeh; $\$ 1.20$ per ten; $\$ 10.00$ per hundred.

8/15 Mrs. Wm. Dickham.-Large, Japanese reflexed. One of the best exhibition yellows. Dwarf.

16e eaeh; soe per ten; \$6.00 per hundred.

8,10 Mrs. Wm. H. Walker.-Color lemon yellow and one of the very largest. Fine dwarf habit.

15e eaeh; \$1.20 per ten; \$10.00 per hundred.

\$/25 Nakota.-(Introduced by us 1913.) Owing to its immense size has become very popular for exhibition purposes. Orange-buff. Semi-dwarf.

15e each; $\$ 1.20$ per ten; $\$ \$ 10.00$ per hundred.

8/10 Nellie Poeket.-Irregular incurved Japanese, narrow twisted petals, creamy white, first bud Dwarf. 10e eaelı; soe per ten; \$6.00 per hundred.

9/5 Nerissa.-(Introduced by us 1914.) Owing to its enormous size, fine form and finish, is conceded to be one of the best exhibition sorts. Color rosy-nauve. Strong, upright growth with rigid stem. Well adapted for specimen plants. Dwarf.

15e eaeh; \$1.20 per ten; $\$ 10.00$ per hundred.

$8 / 30$ Odessa.-(Introduced by us 1914.) A seedling from Merza, but niuch freer in growth and better in every way. Splendid incurved form, bright yellow. It eclipses all the yellows in size and finish. Equal to William Turner. Tall. 15e eaeh; \$1.20 per ten; \$10.00 per hundred.

$8 / 20$ o. H. Broomhead.-A large bloom, with long, broad reflecting petals; color, rose pink. Dwarf.

15e eaeh; \$1.20 per ten; $\$ 10.00$ per hundred.

8/25 Ongawa.- (Introduced by us 1907.) Color, golden amber; easy to grow; fine stem and foliage. One of the best for the Pacific Coast. Semi-dwarf. 15e eaeh; \$1.20 per ten; \$10.00 per hundred.

$8 / 30$ Perle Franeaise.-Enormous in size, petals reflecting and curling at tips. Color, soft lavender pink, shading to white. Semi-dwarf. 15e eaeh; \$1.20 per ten; $\$ 10.00$ per hundred. 
7/25 Queen Mary.-Will not develop from July buds and is single from later ones throughout the Middle West. Could be grown to greatest perfection in Northern California. One of the finest whites when well grown. Dwarf.

15e each; $\$ 1.20$ per ten; $\$ 10.00$ per Inudred.

$8 / 10$ Poekett's Crimson.-Crimson with gold at tips of petals, which stand out, showing the color to good advantagc. Divarf.

15e each; \$1.20 per ten; $\$ 10.00$ per humdred.

$8 / 25$ Poekett's surprise.-Rosy crimson with cinnamon bronze reverse; long, broad florets. Japanese incurved; foliage heavy and good stem. Semi-dwarf. 15e eaeh; \$1.20 per ten; $\$ 10.00$ per humdred.

8/15 Poughkeepsic.-(Introduced by us 1909.) Full exhibition size; in fact, is larger than Merza. White, with slight creamy cast. Tall. 15e eaeh; \$1.20 per ten; $\$ 10.00$ per hundred.

$8 / 30$ Pres. Taft.-(Introduced by us 1909.) Japanese incurved of the purest white, which closely incurve; stem and foliage good. Semi-dwarf. 10e each; Soe per ten; \$6.00 per hundred.

8/25 Reginald Vallis.-A large Japanese, plum color with lighter reverse. Can be grown to enormous size with excellent finish. Tall. 15e each; \$1.20 per ten; \$10.00 per hundred.

8/15 Rose Pceket.-Light shade of yellow, with an occasional tint of bronze. The wide petals incurve at the center and the outer ones reflex. Semi-dwarf. 10e each; soc per ten; \$6.00 per hundred.

\&/25 Silver King.- (Introduced by us 1915.) Large reflex white, splendid for collections. Wonderful stem and foliage. Tall.

15e each; \$1.20 per ten; \$10.00 per hundred.

8/20 Tarrytown.-(Introduced by us 1911.) Large, light rosy salmon of a pleasing shade; quite similar to that of W. A. Etherington. Petals irregularly arranged. Dwarf.

10e eaeh; soe per ten; $\$ 6.00$ per hundred.

$8 / 25$ T. Carrington.-Growth vigorous, amaranth, large. Owing to its distinct color, is unrivalled for classes calling for any other color than white, pink, yellow, etc. Semi-dwarf.

15e each; \$1.20 per ten; \$10.00 per hundred.

9/10 Thanksqiving Queen.-(Introduced by us 1911.) Very large, creamy white, and comes just right for Thanksgiving. Strong stem, and so upright and sturdy in growth as scarcely to require tying. Dwarf.

15e each; \$1.20 per ten; $\$ 10.00$ per hundred.

8/29 Wells' Late Pink.-A very pleasing shade of pink and of the largest size; not late as the name implies.. Dwarf.

15e each; \$1.20 per teu; \$10.00 per hundred.

8'15 Wm. Duekham.-Beautiful light pink, Japanese incurved. Owing to its freedom of growth, pleasing color, and sturdy stem, is deservedly popular. Dwarf.

15e eaeh; $\$ 1.20$ per ten; $\$ 10.00$ per hundred.

$8 / 30$ Wm. Turuer.-A decided incurve of the purest white; fine form and a strong grower with clean foliage. Semi-dwarf.

15e caeh; $\$ 1.20$ per ten; $\$ 10.00$ per hundred.

$8 / 20$ Wn. Vert.-Bright crimson of large size; form reflexed; growth strong. Semidwarf.

20e eneh; \$1.75 per ten; \$12.00 per hunded.

8/5 W. Woodmason. - The largest red; not as bright in cclor as many of the crimsons, but its size enhances its value. Dwarf.

20e each; \$1.75 per ten; \$12.00 per hundred.

8:20 Yellow Miller.-A clear light yellow sport from Mrs. J. A. Miller. Foliage and stem good. Semi-dwarf.

10e eaeh; soe per ten; \$6.00 per hundred.

\section{Read This Before Making Order}

Remember, we do not supply less than 5 plants at ten and 25 at hundred rate. This does not mean 5 or 25 different varieties at ten or hundred rate.

For example: If ten rate is desired make order read 5 Wm. Turner, 5 Elberon, 5 Odessa, etc. If less than 5 are ordered multiply number of plants by price quoted per each. 


\section{Commercial Section}

The varieties best suited for the commercial grower are those which have sturdy: upright growth, with good stem and foliage, are of pleasing color and (with the exception of a few early varieties) produced double flowers from the late or terminal bud. We have endeavored to give the height the plants attain and best date to reserve buds. In giving the height it must be considered only approximate, as much depends upon the size of plants at planting time and conditions maintained thereafter.

\section{New American \\ Chrysanthemums for 1917 Originated by Elmer D. Smith \& Co.}

Delivery on or before March 1st. Not less than 5 plants of a variety at ten, and 25 at hundred rate.

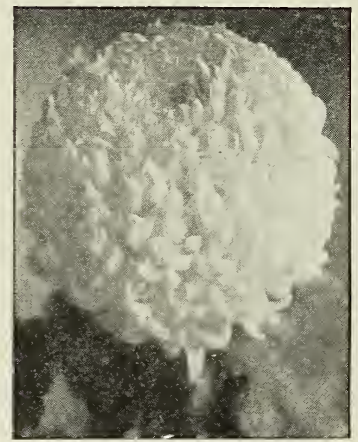

Smith's Imperial

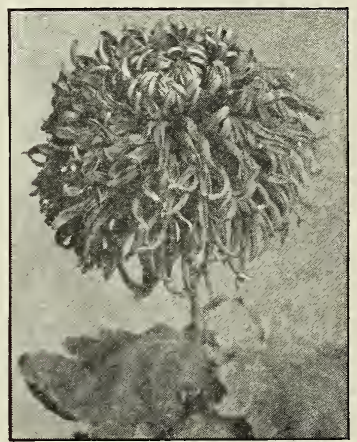

October Herald

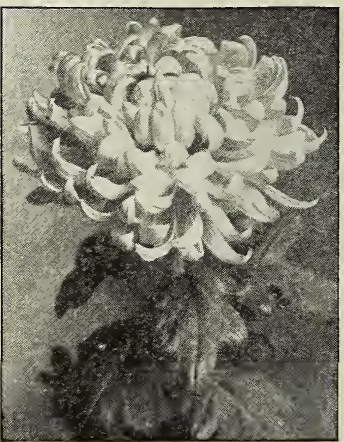

Yondota

Smith's Imperial.-We consider this one of our greatest achievements in the improvement of Commercial Chrysanthemums. An incurved white, fully developed October 22nd, good from any bud August 25th, and after. Dwarf habit, 4 1/2 ft.; from May planting will produce three to four perfect flowers per plant for those who prefer them only medium size. Has abundant dark, glossy foliage extending to the bloom, shortjointed, ridged stem. Recommended for certificate by all five of the C. S. A. Committees.

Price-75e each; $\$ 6.00$ per ten; $\$ 50.00$ per hundred.

Oetober Herald.- - n orange yellow, similar in color to old Gold or Modello; in form reflexed with somewhat twisted petals. Best blooms from buds selected August 25th, and may be grown eight inches or more in diameter. Strong upright growth, 41/2 to $5 \mathrm{ft}$., from May planting, with good stem and foliage. Its striking color invariably brings forth the strongest expressions of admiration from all lovers of the Chrysanthemum. C. S. A. Cert.

Price-75c each; $\$ 6.00$ per ten; $\$ 50.00$ per hundred.

Fondota.-Owing to the extreme scarcity of good early pinks, we are prompted to submit this variety to the public, with the assurance it will meet general favor. A beautiful shade of rose pink, entirely free from the objectionable magenta shade so often found in pink Chrysanthemums; matures October 25th, from buds selected August 25th. Flowers from later buds are inclined to show the center, but if cut before fully developed will find ready demand, as it appeals to all who are partial to this color. Stem and foliage excellent, $5 \mathrm{ft}$., from May-planted stock. C. S. A. Cert.

Price-75e each; $\$ 6.00$ per ten; $\$ 50.00$ per hundred. 


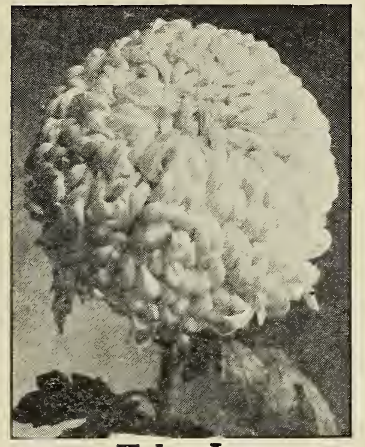

Helen Lee

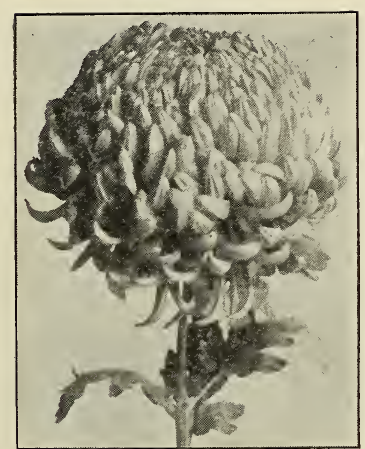

December Queen

Helen Lee.-Belongs to the Midseason section, maturing the first week in November. Color a very delicate flesh or light Enchantress Carnation color. Very perfect incurved form, excellent stem and foliage, height $4 \mathrm{ft}$. Select bud the last of August. C. S. A. Cert.

Price-75e each; $\$ 6.00$ per ten, $\$ 50.00$ per hundred.

December Queen.-The latest yellow Chrysanthemum, maturing November 25 th to December 5 th, ô unusual size considering the lateness, being $7^{\prime \prime}$ to $8^{\prime \prime}$ in diameter. Color bright yellow, approaching orange, slightly penciled with red. but as it is of the best incurved form these markings are scarcely noticed. Is darker in color than Golden Chadwick and Nagoya, the two best late yellows in commerce. Double to the center from buds selected September 20 th to 30 th; early ones will not develop. Four feet from June planting. C. S. A. Cert. Price-75e each; $\$ 6.00$ per ten, $\$ 50.00$ per hundred.

Owing to limited stock we may defer distribution to early March.

\section{INTRODUGTION OF 1916}

Best blid.

9/10 Autoerat.-Late midseason, same time as Timothy Eaton. Pure white, fine incurved form with good stem. 25e each; $\$ 2.00$ per ten; $\$ 15.00$ per hundred.

8/20 Early Rose.-Rose color, as name implies, of a bright pleasing shade. Matures October 15 th, very dwarf. Hoc each; $\$ 3.00$ per ten; $\$ 25.00$ per hundred.

8/20 Golden Gleam.-Robust in growth, color bright yellow, fine stem and foliage. 25e each; $\$ 2.00$ per ten; $\$ 15.00$ per hundred.

8/25 Josephine Foley.-The best pure white introduced in 1916 . Of sufficient size to be serviceable in the exhibition class. 40e each; \$3.00 per ten; \$25.00 per hundred.

$9 / 10$ Mrs. M. R. Morgan.-Bright yellow, a sport from Yellow Eaton, of the reflexed tyre. Gocd for Thanksgiving. 15e eaeh; \$1.20 per ten; \$10.00 per hundred.

8/25 October Queen.-Of large size and purest white, incurved, attractive foliage and strong stem. 40e each; \$3.00 per ten; $\$ 25.00$ per hundred.

9/5 Tiger.-(Name supplied by President Wilson)-One of the very best commercial yellows. Flowers very full, bright in color with excellent stem. 40c each; $\$ 3.00$ per ten; \$25.00 per hundred. 


\section{STANDARD VARIETIES}

To secure early flowers it is of the utmost importance they be planted early. Good, strong plants from 3-in. pots benched in May give very satisfactory results.

Each section is arranged according to time of flowering from early to late approximately.

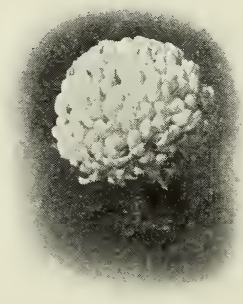

$10 \mathrm{c}$ each; $80 \mathrm{c}$ per ten; $\$ 6.00$ per hundred, except where otherwise quoted.

Not less than 5 plants of a variety at ten, 25 at hundred rate.

\section{WHITE.}

\section{EARLY FROST}

SMITH'S ADVANCE

CRYSTAL GEM

OCONTO

NAOMAH

WHITE CHIEFTAIN

TIMOTHY EATON

WHITE PERFECTION

CHADWICK IMPROVED

15c each; $\$ 1.00$ per ten; $\$ 7.50$ per hundred.

W. H. CHADWICK

15c each; $\$ 1.00$ per ten; $\$ 7.50$ per hundred.

WHITE BONNAFFON

WHITE HELEN FRICK

DECEMBER GEM

JEANNE NONIN

RED.

GARNET GEM

DICK WITTERSTAETTER

HARVARD

ANTIQUE

BRONZE.

\section{YELLOW.}

GOLDEN GLOW
GOLDEN QUEEN
CHRYSOLORA
MODELLO
ROMAN GOLD

GOLDEN EATON

MAJOR BONNAFFON

IMPROVED GOLDEN CHADWICK

15c each; $\$ 1.00$ per ten; $\$ 7.50$ per hundred.

NAGOYA

\section{PINK.}

UNAKA

PACIFIC SUPREME

CHIEFTAIN

PRES. ROOSEVELT

DR. ENGUEHARD

PATTY

E. A. SEIDEWITZ

HELEN FRICK

The following additional Commercial sorts we can supply: Chas. Rager, Early Snow, Gloria, Glory of Pacific, Ivory, Mrs. B. E. Hayward, Pink Ivory, Polly Rose. Rosiere, White Gloria, Yellow Ivory, Col. D. Appleton, Mary E. Meyer, Mrs. H. Robinson, Pink Gem, Ramapo, Smith's Ideal, Smith's Sensation, Western King, Yellow Eaton, Mistletoe, Golden Chadwick, Mrs. W. T. McNeice. 


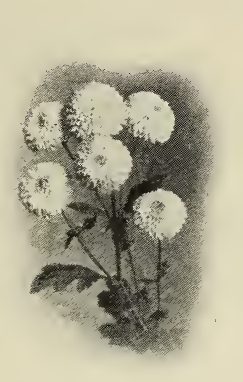

\section{POMPON SECTION}

Pompons are becoming more popular year by year, being especially desirable for pot plants, and lend a distinctive grace and beauty to floral decorations of all kinds.

\section{New American Chrysanthemums for 1917}

Originated by Elmer D. Smith \& Co.

\section{NEW POMPON}

Jitte Gem.-A seedling from the little yellow of Japanese origin, kncwn as Baby, and possesses the same form of pedal, but is somewhat larser, about one inch in diameter. Color, a very pleasing shade of lavendar pink. Strong upright growth, in perfection first week of November. Entirely distinct from any Pompon. An acquisition to those desiring artistic arrangements, and the commercial grower need have no hesitancy in securing this striking novelty, as strong demand is assured. At Cleveland, in 1915 , Little Gem was given the highest scoring of any seedling submitted, not excepting the large flowering by the C. S. A. Judges.

Price-50e each; $\$ 4.00$ per ten; $\$ 30.00$ per hundred.

\section{INTRODUCTION OF 1916}

NORDI.-A pure white Pompon, maturing November 10 th to Thanksgiving. Seven to eight medium sized flowers to the spray, with strong wiry stem. From equal space this variety will double the quantity of sprays to those produced by either Helen Newherry or Lulu, the best two late white Pompons in commerce.

15c each; \$1.20 per ten; \$10.to per hundred.

MORA.-This variety we were unable to disseminate last year owing to the misfortune of losing most of stock. An early bright yellow maturing October 15 th to 20th, nice large sprays coming a few days ahead of Zenobia. This is the earliest good yellow Pompon we know of.

35e each; $\$ 3.00$ per ten; $\$ 25.00$ per hundred.

PEACE.-Flowers large for a Pompon, delicate pink, best disbudded.

15. eaelı; $\$ 1.20$ per ten; $\$ 10.00$ per hundred.

\section{STANDARD VARIETIES}

10e each; T5e per ten; $\$ 5.00$ per humdred.

Not less than 5 plants of a variety at ten, 25 at hundred rate.

Baby.-Clear bright yellow; very late.

Celco.-(Introduced by us 1914.) Bright yellow, approaching orange; similar to that of Golden Climax, only a little flatter in form, but will produce two to three times as many flowers to an equal space. Medium sized. Tall.

Clorinda.- (Introduced by us 1910.) Semi-dwarf, producing erect sprays of an even shade of bronze. One of the best for specimen plants.

Diana.-A fine pure white.

Fairy Queen.-A delightful deep Encliantress color, of medium size, round and full, elegant foliage and a good keeper.

Frank Wilcox.-(Syn. Mrs. Beu and Souv. d'Or). Golden bronze of special merit to those desiring late Pompons.

Golden Climax.-A very pleasing shade of bright yellow; medium size and height.

Golden Harvest.-Very similar to Golden Climax, except it has a tinge of bronze added to the yellow.

Golden West.-A small golden yellow flower of great substance. Dwarf.

Helen Newberry.-The latest white Pompon; just as good and a little better than the popular variety Diana, which it follows for Thanksgiving and up to Christmas. 
Illona.-(Introduced by us 1915.) Rosy lavender, much the same color as Western Beauty but produces larger sprays, hence is more profitable. Large; height medium. November 10 th.

Iva.- (Introduced by us 1908.) Pure amber; fimbriated petals; medium size.

Julie Lagravere.-Deep red; best of its color. Late.

Klondike.-Brilliant yellow; compact blooms of medium size.

La Purite. $-\Lambda$ beautiful pure white.

Leota.-(Introduced by us 1914.) Delicate pink, maturing October 20th, and produces large, full sprays; one of the very best; medium size. Dwarf.

Lillia.-Deep bronzy red; tall, upright growth; medium size.

Lillian Doty-Flowers beautiful shell pink, best grown to several leads and disbudded to one bloom. Strong, upright growth.

Lulu.-Pure snow white of medium size. Late.

Madge.-Very perfect in form, golden yellow, same shade as Golden Harvest and the best of the two. Medium size. Dwarf.

Iinta.-(Introduced by us 1911.) A very free flowering light pink, unsurpassed by any of this color. Owing to its upright growth it is one of the best for specimen plants.

Ncola.-(Introduced by us 1915.) Light pink, strong growth with a stem like Quinola; needs very little tying. Large, maturing November 15 th to 25 th. Dwarf.

Niza.-(Introduced by us 1915.) Delicate pink and the earliest of this color, maturing October 10 th. Those desiring early Pompons should secure this variety. Medium sized flower's. Dwarf.

Quinola.-Clear orange yellow; excellent form and good size.

Rodi.-(Introduced by us 1915.) The best of its color, purplish rose. Large, strong, upright growth. Tall.

Skibo.-(Introduced by us 1905.) Golden chamois; flowers small.

Veta.-(Introduced by us 1915.) Small, pure white flowers; very free. Resembles the old variety Snow Drops, but produces much larger sprays; will supercede Baby Marguerite. Dwarf.

Western Beauty.-Flower large, deep rose pink, stiff, upright growth.

Zcnobia.-Bright, clear yellow. Early.

\section{NEW LATE ANEMONE}

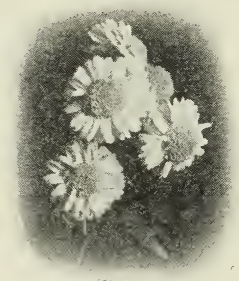

The Crest.-Maturing the end of November and may be kept well into December. Owing to the guard petals being very long we cannot recommend this variety to those consigning their stock, but to those retailing their products it will be a welcome addition to the late flowering section. Is also an acquisition for those desiring pot plants for late decorations. When grown cold we have had it in good condition after Christmas. Pure white, showing traces of pink when allowed to remain on the plants for a long time. This variety originated with James Dowlen, Millbrook, N. Y. C. S. A. Cert.

Price-50e each; $\$ 4.00$ per ten; $\$ 30.00$ per hundred. (See cut back cover.)

\section{TWO ANEMONES OF REGENT INTRODUGTION}

C. L. Hutchinson.-Singie row of white ray florets, center yellow, very dwarf, excellent as a small pot plant. Large.

15e each; $\$ 1.20$ per ten; $\$ 10.00$ per hundred.

Golden Parasol.-Rays and disc both bright yellow. Isarge.

15e each; $\$ 1.20$ per ten; $\$ 10.00$ per hundred.

\section{STANDARD VARIETIES}

10 c cach; 55e per ten; $\$ 5.00$ per hundred.

Not less than 5 plants of a varicty at ten, 25 at hundred rate.

Alpine Glow.-Large white flower with a glow of pink; very beautiful.

Ada Sweet.-Silvery pink, medium size flower; petals mostly quilled; fine for pots.

Azelda.- Introduced by us 1914.) Light pink, shaded lavender; rays and disc florets same shade, except center of cushion, which is cream color.

Beatrice Asmus.-Beautiful pure white petals; flat and substantial.

Bessie Flight.-Bright, rosy pink, center full. A sport from Mme. Montels.

Diantha.-(Introduced by us 1913.) Dwarf, compact growth; fine for small pot plant or to grow for sprays. Guard white, high rounded cream-colored center.

Garza.-Purest white with yellow center; medium size; rays broad. 
Godfrey's Perfection.-Resembles Garza, being same size and pure white, but is a better shipper, having four or five rows of ray florets instead of one. Matures for Thanksgiving and is one of the best of recent introductions. Dwarf, making excellent pot plants, 25e each; $\$ 2.00$ per ten; $\$ 15.00$ per hundred.

Golden Lida Thomas.-A golden yellow sport from Lida Thomas, and, like its parent, matures just right for Thanksgiving. Good in every way. We consider this the best for florists' use. 25e each; $\$ 2.00$ per ten; $\$ 15.00$ per hundred. late.

Lida Thomas.-Small flower, white, two rows of flat petals, center delicate yellow;

Mary Colladay.-A seedling of Garza, with habit of parent; in color, a rich rosy lavender pink. Extremely free and of excellent keeping qualities.

Miss Katherine Simmons.-Soft pink; one row of quilled petals loosely arranged; yellow center.

Mrs. Jacob Wellauer.-Beautiful lilac color; flat petals; large honeycombed center.

Mrs. Shimmins.-Apricot, shading to red. Belongs to the large flowering section. Semi-dwarf and free.

Princess.-Very similar to Garza, the principal difference being it has strap-shaped ray florets instead of semi-tubular. Is much freer of propagation and in our opinion oetter than Garza for general use.

Surprise.-Pink, very large and good.

Yellow Garza.-A yellow sport from Garza, identical in other respects.

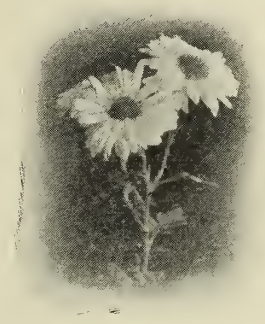

\section{SINGLES}

This section comprises the best varieties for cut sprays and are also useful for specimen plants. Those listed below we consider best.

10c each; 75c per ten; $\$ 5.00$ per hundred, unless otherwise quoted.

Not less than 5 plants of a variety at ten, 25 at hundred rate.

Anua.- (Introduced by us 1909.) Pure white; belongs to the true single section, having but one row of petals. Fine for pot plants.

Blazing star.-(Introduced by us 1913.) The best bright single red to grow for sprays.

Caledonia.-Beautiful shade of pink and very useful for those retailing their crop; not a good shipper.

Catherine livingstone.-A pleasing shade of lavender pink; strong grower and produces fine sprays.

Ceddie Mason.-A fine scarlet crimson; long stem; very free.

Clea.-(introduced by us 1912.) Growth upright, forming large sprays of a delicate shade of light pink.

Golden Mensa.-Doubtless the best single yellow for general purposes.

Hilda Wells.-Beautiful Tuscan red with a light yellow tinting at base of petals.

Indicum.-Yellow, very small. The original wild variety from China.

Itaska.-(Introduced by us 1910.) Bright pink, petals incurving like R. B. Burge; late. Josephiue.-A splendid single yellow of exceptional merit.

Cady Lu.-Purest white; good for all purposes.

Iadysmith.-Early pink; useful for bush plants.

Little Barbee.-Clear canary yellow; exceptionally large sprays of medium sized flowers. This we consider the best yellow, either for cutting or pot culture.

Mensa.-One of the largest single whites; produces freely on long, stiff stems.

Merstham Jewel.-Terra cotta, with golden points and center.

Iinuesota.-A very striking blood red, 21/2. in. across; long, slender stem; best red tor general use.

IIiss Isabelle.-Bronzy amber sport from Mrs. E. D. Godfrey. Good for late cutting. Mrs. E. D. Godfrey.-Very strong grower. Light pink. Excellent as a late single.

Mrs. Wm. Buckingham.-A large, flat flower of a lovely shade of rosy pink, and lieeps well, both on or off the plant.

Iolly Duncan.-Canary yellow; large flower, borne erect; very desirable.

Queen.-(Introduced by us 1913.) The best late single white, maturing from Thanksgiving into December.

Stanley Ven.-Rose color, producing loose and graceful sprays. One of the best.

Sylvia slade.-Rosy garnet, with white ring around the disc; distinct and good. 


\section{EARLY HARDY SECTION.}

The majority of Chrysanthemums are hardy south of the Ohio river and many are haldy in the northern states, as far as the plant is concerned, but they must flower before early frosts to be of service. The varieties offered below generally flower from the last of August to the 15 th of October.

15e each; \$1.20 per ten; \$10.00 per hundred.

Not less than 5 plants of a variety at ten, 25 at hundred rate.

The small or Pompon varieties are so indicated in the descriptions, the others have larger flower's more like Asters.

A. Barham.-Beautiful orange bronze. Early.

Billancourt.-Brilliant terra-cotta, vigorous grower.

Boston.- Strong upright growth, clear bronze.

Cactus.-Fiery terra cotta, shape of a small cactus, very free and effective.

Carrie (Syn. Glory of Seven Oaks.)-Deep yellow, a beauty.

Chaldron.-Reddish crims on with gold tips. Large flower.

Champagne.-Bright ruby red; wonderfully colored.

Champ d'or.-Canary yellow; very bushy habit.

Cranfordia.-Exceptionally early, deep bronzy yellow.

Cranfords Pink.-Beautiful shade of light pink.

Cransford White--Purest white, very desirable. tion.

Daisy.-A pure white daisy-like flower, belongs to the Pompon or small flowered sec-

Dorothy.-An early snow white, vigorous.

Eden.-Bright rose; a brauty disbudded. free.

Gold Nugget.-Belongs to the Pompon section. Yellow streaked bronze. Early and

Harvest Home.-Deep bronzy yellow, excellent.

Hermine.-A pure white, reflexed.

Holmes White.-Pure white, dwarf and very hardy.

Lady Mary Hope.-White, slightly shaded blush; good habit.

La Somme.-Deep mauve pink.

Le Pactole.-Bronzy yellow, large flower, strong grower.

Little Bob.- Small red flowers, very free and pretty; belongs to the Pompon section.

Ime. Drouard.-Deep brick red, very free flowering.

Miss F. Collier.-Pure waxy white. Sturdy dwarf growth.

IIrs. Porter.-Large reddish bronze; strong grower.

Normandie.-One of the earliest and best creamy whites.

Petite Louis.- Silvery mauve, very robust; one of the best. onward.

wimnetka.- (Introduced by us 1914.) Pure white, very free flowering from July

\section{DECORATIVE SECTION.}

The following varieties are especially adapted for the production of large or small specimen plants. Where large specimens are required, they should be started in January or February. Medium sized plants can be produced from cuttings struck in March, and for those who desire to grow small sizes for market trade, this work may be continued until the middle of June.

15e each; \$1.20 per ten; $\$ 10.00$ per hundred.

Not less than 5 plants of a variety at ten, 25 at hundred rate.

August Dasse.-Very solid flower of excellent keeping quality, globular in form; color, intense yellow. Dwarf.

Brutus.-Beautiful shade of bronze, most useful as a specimen plant. Dwarf.

Butler's Capriee.-Sport of Caprice du Printemps. Deep pink. Dwarf.

Golden Robin.--(Introduced by us 1913.) An improved Golden Age, either as a specimen plant or for commercial yellow. Golden WVedding is light yellow by comparison. Dwarf.

Greystone.-This variety comes highly recommended as one of the best for spectmen plants. Color, beautiful golden orange. Dwarf.

Halloween.- (New 1916.) Reddish bronze, matures last of October.

Kathleen Thompson.-A fine crimson. Dwarf.

Lady Lydia.-Pure White. Dwarf.

Lilac Caprice.-Deep lilac. Dwarf.

Purple Capriee.-Purple. Dwarf.

White Caprice.-White. Dwarf.

Jellow Capriee.-Clear yellow. Dwarf. 


\section{Smith's \\ Revised Chrysanthemum Manual}

(THIRD EDITION.)

\section{By ELMER D. SMITH}

Who has made a Specialty of Chrysanthemum Culture for the past Twenty-five Years.

This bocklet treats the subject in a concise yet lucid manner, covering the whole work from the care of stock plants to the staging of blooms.

The best work on American Chrysanthemum Culture. Both amateur and florists have been provided with articles for their special needs.

\section{CHRYSALINE The Ideal Plant Food}

We regret our inability to accept orders for Chrysaline. Some of the ingredients entering into this preparation have advanced from 500 to $1000 \%$ in the past two years. For this reason those who have depended upon Chrysaline in the development of their plants, should endeavor to seek some other agency to promote healthy growth, at least until prices for such commodities recede. 


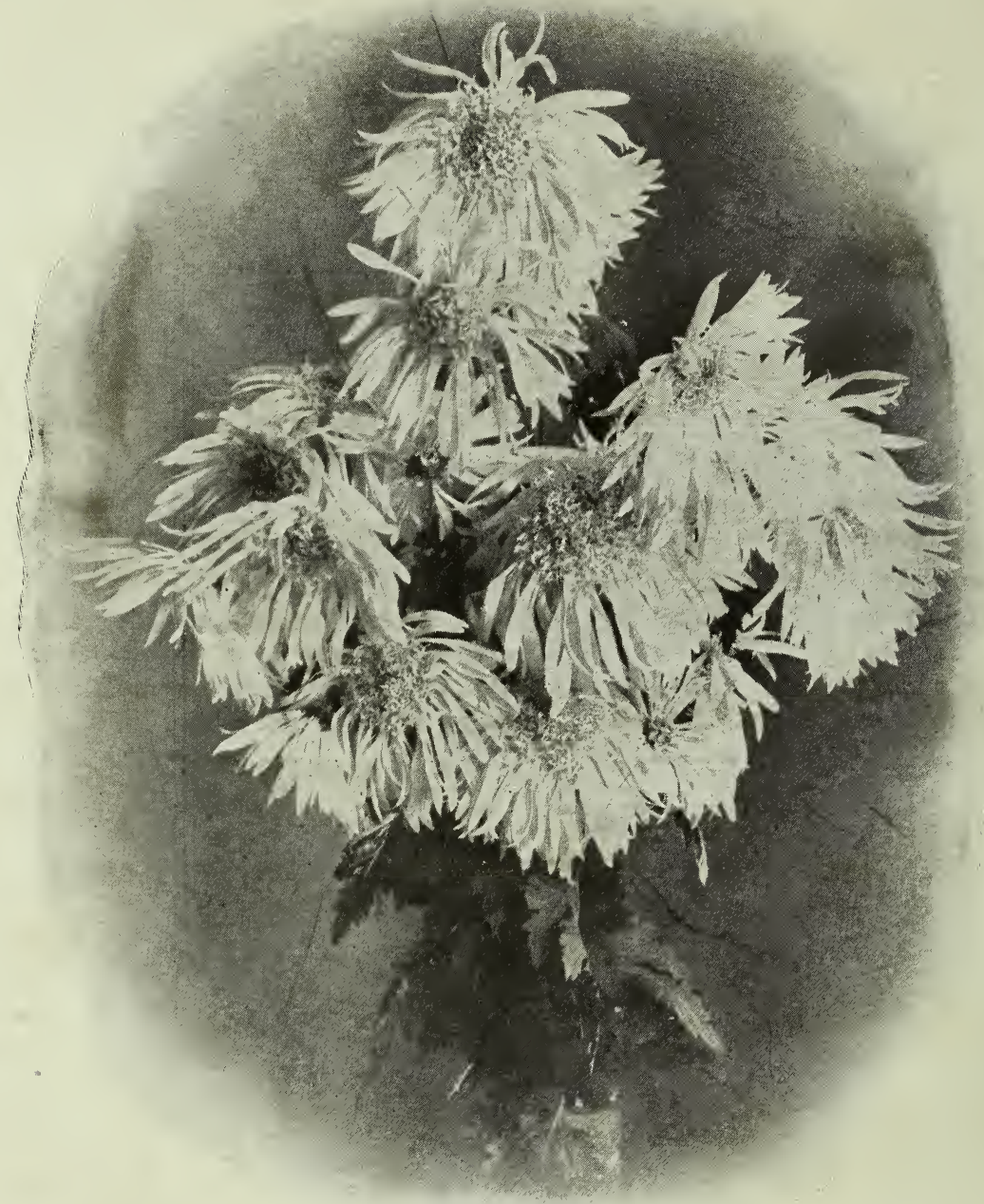

THE GREST

\section{ELMER D. SMITH \& CO. Chrysanthemum Specialists ORIGINATORS AND DISSEMINATORS}

The only firm in America devoted entire'y to Chrysanthemum Culture 